\title{
THE SERUM PROTEINS OF HEALTHY ADULT NIGERIANS
}

\author{
BY \\ J. C. EDOZIEN \\ From the Department of Chemical Pathology, University College, Ibadan, Nigeria
}

(RECEIVED FOR PUBLICATION JULY 19, 1956)

Chemical and electrophoretic analyses of the serum proteins have become routine diagnostic investigations in many hospital laboratories. The albumin/globulin ratio decreases in a variety of disease conditions, including liver diseases, the nephrotic syndrome, protein malnutrition, myeloma, etc. It is therefore very important that the normal variations in the albumin-globulin ratio should be well understood if serious errors in interpretation are to be avoided.

Routine analyses of sera sent to our laboratories at Ibadan have made it apparent to us that the distribution of albumin and globulin in the serum of apparently healthy adult Nigerians is significantly different from that generally accepted as normal in Europeans. In most of these sera we find that ratio depressed, which in many cases may be less than 1, and yet we can find no other evidence of any of those diseases which are generally believed to cause a depressed albumin/globulin ratio. We therefore decided to carry out a study of the serum proteins of healthy adult Nigerians with a view to establishing normal values for the local population. The following communication is a record of the results.

\section{Methods}

Total proteins and albumin were determined by the biuret method of Reinhold (Reinhold. Steward, and Gilman, 1950 ; Reinhold, 1953), using the biuret reagent of Gornall (Gornall, Bardawill, and David. 1949 ; King, 1951). This method was found to give results which agreed very closely with duplicate samples analysed by the micro-Kjeldahl procedure. The globulins were precipitated by a sodium sulphate / sodium sulphite mixture which gives values for albumin and total globulins approximating more to the electrophoretic results than Howe's fractionation procedure using $23 \%$ sodium sulphate.

Zone electrophoresis was performed on $4 \times 36 \mathrm{~cm}$. strips Whatman No. 1 filter paper in a barbitone

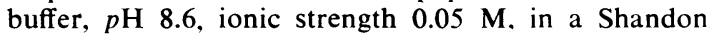
vertical electrophoresis tank, applying $0.05 \mathrm{ml}$. serum to each paper. Adequate separation was obtained in 15 hours in an air-conditioned room (temperature $24 \pm 2^{\circ}$ C.) at 200 volts and a current density of $0.3 \mathrm{~mA} / \mathrm{cm}$. The strips were removed at the end of 15 hours, dried for 30 minutes in a hot-air oven at $105^{\circ} \mathrm{C}$., stained for 10 minutes in $1 \%$ bromphenol blue in absolute ethyl alcohol saturated with mercuric chloride, and then washed in running tap-water until the protein-free filter paper was white. They were then finally dried in a hot-air oven at $105^{\circ} \mathrm{C}$. for 15 minutes. The electrophoretic patterns were drawn from the filter-paper strips by scanning with a commercial photo-electric densitometer. An ott compensating planimeter was used to compute the percentage concentrations of the various protein fractions. The resulting percentages were not multiplied by any coefficient.

\section{Results}

Total Serum Proteins and A/G Ratios.-Table I gives the average results of 200 determinations on healthy adult Nigerians. The sera of 40 Europeans and two Indians who have been resident in Nigeria for periods varying from three months to 15 years were also investigated by the same methods. The average results for Europeans at Ibadan are the same as those of Europeans living in Europe and America and are also shown in Table I. The two Indians had ratios of 1.5 and 1.63 respectively.

TABLE I

RESULTS IN NIGERIANS AND EUROPEANS LIVING IN IBADAN

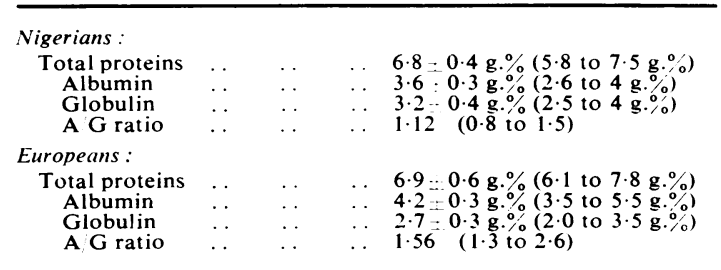


Paper Electrophoresis.-The average results of 50 determinations for Nigerians and of 25 determinations for Europeans are presented in Table II.

TABLE II

AVERAGE RESULTS IN NIGERIANS AND EUROPEANS

\begin{tabular}{|c|c|c|c|c|c|}
\hline & & \multicolumn{2}{|c|}{ Nigerians } & \multicolumn{2}{|c|}{ Europeans } \\
\hline & & g. $100 \mathrm{ml}$. & $\%$ of Total & g. $100 \mathrm{ml}$. & $\%$ of Total \\
\hline $\begin{array}{l}\text { Total proteins } \\
\text { Albumin. } \\
a_{1} \text { Globulin } \\
a_{2} \\
\beta_{1} \\
\gamma \\
\gamma \\
\text { Total globülins } \\
\text { A G ratio }\end{array}$ & $\begin{array}{l}. . \\
\ldots \\
\ldots \\
\ldots \\
\cdots \\
\ldots \\
\ldots\end{array}$ & $\begin{array}{l}6 \cdot 8 \\
3 \cdot 35 \\
0 \cdot 20 \\
0 \cdot 51 \\
0.64 \\
2 \cdot 10 \\
3.45 \\
0.97\end{array}$ & $\begin{array}{r}100 \\
49 \cdot 5 \\
2 \cdot 9 \\
7 \cdot 5 \\
9 \cdot 4 \\
31 \cdot 3 \\
50 \cdot 5\end{array}$ & $\begin{array}{l}6.9 \\
4.05 \\
0.31 \\
0.52 \\
0.82 \\
1.20 \\
2.85 \\
1.42\end{array}$ & $\begin{array}{r}100 \\
58 \cdot 5 \\
4.5 \\
7 \cdot 5 \\
11.9 \\
17.6 \\
41 \cdot 5\end{array}$ \\
\hline
\end{tabular}

The following conclusions may be drawn from the figures presented above:

The total serum proteins of healthy adult Nigerians are approximately the same as those of adult Europeans. It may be mentioned here that the incidence of low serum proteins ( 3 to $5 \mathrm{~g} . \%$ ) is very high in hospital patients, especially in children. The principal causes of this hypoproteinaemia are malnutrition and nephrosis. In both conditions the decrease is mainly in the albumin, but in nephrosis the $\alpha_{2}$ globulin is increased and the serum lipids are raised, while in malnutrition all the globulin fractions are decreased and the serum lipids are invariably low.

The serum of healthy adult Nigerians contains a lower concentration of albumin and a higher concentration of globulin than the serum of adult Europeans.

Compared with the serum of Europeans, the serum of adult Nigerians contains slightly less $\alpha_{1}$ and $\beta$ globulins. The difference is almost certainily related to the lower concentration of lipids in the serum of Nigerians (Edozien, 1956).

The higher concentration of globulins in the serum of Nigerians is due to the high content of $\gamma$ globulin.

\section{Origin of High Globulin Content of Serum of Nigerians}

Four factors have been considered relevant in accounting for this divergence, namely, liver disease, immunity, diet, and genetic factors.

Liver Disease.-In this survey, only apparently healthy adults without liver enlargement and without evidence of hepatic disease have been included. Although a high incidence of cirrhosis of the liver has been reported from certain parts of Africa, this has not been the experience in Nigeria. A pilot survey of the population of Ibadan, using the estimation of thymol turbidities and bromsulphthalein clearances, has not revealed any widespread impairment of liver function.

Immunity.-The pattern of disease in infancy and childhood, and, therefore, presumably the pattern of immune antibody production, vary according to local conditions. Certain diseases endemic in Nigeria, e.g., malaria, are known to cause a decrease in serum albumin and a rise in globulin, though how permanent these changes are is not clear. The effects of some other endemic conditions such as chronic worm infestations and Salmonella infections are not so well known. Much work remains to be done before a positive correlation can become established between the concentration of $\gamma$ globulin and the pattern of immune antibody production.

Diet.-The short-term effect of diet was studied (1) by analyses of the serum of adult Nigerians classified according to income, and (2) by feeding experiments.

The Effect of Income.-This has been considered a short-term effect because, owing to the rapidly rising income of many Nigerians and the changing economic structure of Nigerian society, most Nigerians who now belong to the high income group were not born into that group. Moreover, an increase in income does not necessarily mean an improved diet, especially amongst the uneducated. Therefore in selecting subjects for the high income group preference was given to professional men rather than to semi-literate business men. Table III shows that, although differences in nutritional status exist between the income groups as shown by urinary nitrogen output and total cholesterol, no correlation was found between the $A / G$ ratio and income. The results are those of an average of 25 subjects in each group.

TABLE III

EFFECT OF INCOME ON A G RATIO

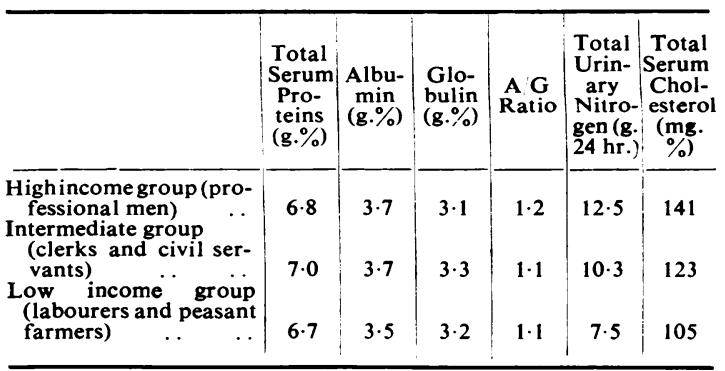


Feeding Experiments.-Six adult male Nigerians aged 20 to 25 years were placed on a diet of approximately $120 \mathrm{~g}$. animal protein (milk, "casilan," and meat), $400 \mathrm{~g}$. carbohydrate, and $100 \mathrm{~g}$. fat per 24 hours for a period of eight weeks. Weekly estimations of total serum proteins, albumin, globulin, serum urea, total output of urinary nitrogen per 24 hours, and serum cholesterol were made. Serum urea and urinary nitrogens were determined by the Conway microdiffusion method. The results are shown in Table IV. During this period the subjects gained weight, the average gain at the end of the experimental period being $8.7 \mathrm{lb}$.

TABLE IV

RESULTS OF FEEDING EXPERIMENTS

\begin{tabular}{c|c|c|c|c|c|c|c}
\hline $\begin{array}{c}\text { No. } \\
\text { of } \\
\text { Weeks }\end{array}$ & $\begin{array}{c}\text { Total } \\
\text { Serum } \\
\text { Protein } \\
(\mathrm{g} . \%)\end{array}$ & $\begin{array}{c}\text { Albu- } \\
\text { min } \\
(\mathrm{g} . \%)\end{array}$ & $\begin{array}{c}\text { Glo- } \\
\text { bulin } \\
(\mathrm{g} . \%)\end{array}$ & $\begin{array}{c}\text { A/G } \\
\text { Ratio }\end{array}$ & $\begin{array}{c}\text { Serum } \\
\text { Urea } \\
\text { (mg. } \\
\%\end{array}$ & $\begin{array}{c}\text { Total } \\
\text { Urinary } \\
\text { Nitrogen } \\
(\mathbf{g} . / 24 \text { hr. })\end{array}$ & $\begin{array}{c}\text { Total } \\
\text { Serum } \\
\text { Chole- } \\
\text { sterol } \\
\text { (mg.\%) }\end{array}$ \\
\hline 0 & 6.7 & 3.6 & 3.1 & 1.1 & 16 & $7 \cdot 1$ & 103 \\
1 & 6.6 & 3.5 & 3.2 & 1.1 & 18.1 & 7.9 & 108 \\
2 & 6.8 & 3.6 & 3.2 & 1.1 & 18.7 & 8.7 & 112 \\
3 & 6.7 & 3.5 & 3.2 & 1.1 & 21 & 10.5 & 120 \\
4 & 6.7 & 3.6 & 3.1 & 1.1 & 23 & 13.5 & 123 \\
5 & 6.8 & 3.6 & 3.2 & 1.1 & 23 & 16 & 127 \\
6 & 6.7 & 3.6 & 3.1 & 1.1 & 22 & 16 & 125 \\
7 & 6.7 & 3.5 & 3.2 & 1.1 & 23 & 15.5 & 131 \\
8 & 6.9 & 3.6 & 3.3 & 1.1 & 23 & 16 & 127 \\
\hline
\end{tabular}

The average daily output of nitrogen of this group at the beginning of the experiment was about $8 \mathrm{~g}$., allowing $1 \mathrm{~g}$. for loss in faeces and through other channels. This is equivalent to a protein intake of $50 \mathrm{~g} . / 24$ hours, assuming that there was nitrogen balance. About two-thirds of this would normally be vegetable protein. This protein intake, although adequate to maintain the total serum proteins at normal levels and to prevent any signs of protein malnutrition, is evidently not the optimum, since nitrogen retention continued for four weeks following the administration of a high protein diet. Table IV also shows clearly that the administration of a large amount of animal protein over the limited period of eight weeks did not produce any immediate change in the relative concentrations of albumin and globulin in the serum. This finding is not in agreement with the work of Holmes, Stanier, Semambo, and Jones (1951), who found that " the albumin levels increase and approach the European mean when the subjects are placed on a good diet."

One factor which has not been adequately studied and which may be of some importance is the long-term effect of a protein intake slightly deficient in quantity and perhaps in quality, but not to such an extent as to impair normal growth and development. It must be remembered, however, that this protein-poor diet is not peculiar to Nigeria but is prevalent in most tropical countries of Africa and Asia. Yet the finding of a low albumin concentration is not the general experience in all tropical countries. Reports from India, for instance (Seth and Dutta, 1955 ; Lal, 1954), indicate that the $A / G$ ratios of Indians average the same as those of Europeans despite the prevalence of a low protein diet. It is therefore concluded that diet alone cannot account for the low $A / G$ ratios found in most Nigerians.

Genetic Factors.-A low albumin and high globulin has also been found in the serum of Africans in Uganda (Holmes et al., 1951 ; Stanier, 1953 ; Stanier and Thompson, 1954), and in the Belgian Congo (van Oye and Charles, 1951). It is also significant that Reinhold, Rawnesley, and Yonan (1955) have demonstrated that a significant difference exists between the zinc sulphate turbidity reading of healthy negroes and whites in America. They found that the average value of the former was $7.30 \pm 1.78$ and that of the whites was $4.97 \pm 1.44$ Shank-Hoagland units. Unlike most of the other turbidity tests the zinc sulphate turbidity depends entirely on the $\gamma$ globulin of the serum and is a relatively accurate index of the concentration of $\gamma$ globulin (Kunkel, 1947 ; Discombe, Jones, and Winstanley, 1954). We have found a similar discrepancy in Nigeria, for whereas the zinc sulphate turbidity values for Europeans is 2 to 8 Maclagan units (average 3.9 units) the normal value for Nigerians is 6 to 14 units with an average of 8.5 units.

Hereditary factors thus seem to be of considerable importance, though much more information is required regarding the serum proteins of people of African descent born and bred under conditions of diet, health, and sanitation superior to those presently existing in most of the African continent before the full significance of the genetic factor can be finally assessed.

\section{Summary}

The serum proteins of healthy adult Nigerians have been studied by chemical fractionation and zone electrophoresis on filter paper.

The serum of healthy adult Nigerians contains $\stackrel{0}{\frac{D}{D}}$ a lower concentration of albumin and a higher $\stackrel{\leftrightarrow}{\oplus}$ concentration of globulin than the serum of adult Europeans. This higher concentration of globulins in the serum of Nigerians is due to a high content of $\gamma$ globulin.

It is concluded that this $\gamma$-globulinaemia is not related to liver disease or diet but may be genetically determined. 
REFERENCES

Discombe, G., Jones, R. F., and Winstanley, D. P. (1954). Journal of Clinical Pathology, 7, 106.

Edozien, J. C. (1956). In press.

Gornall, A. G., Bardawill, C. J., and David, M. M. (1949). J. biol. Chem., 177, 751.

Holmes, E. G., Stanier, M. W., Semambo, Y. B., and Jones, E. R. (1951). Trans. roy. Soc. trop. Med., 45, 371.

King, E. J. (1951). In Recent Advances in Clinical Pathology, 2nd ed., edited by Dyke, S. C. Churchill, London.

Kunkel, H. G. (1947). Proc. Soc. exp. Biol. (N.Y.), 66, 217.

Lal, S. K. (1954). Indian J. med. Res., 42, 215.
Oye, E. van, and Charles, P. (1951). Ann. Soc. belge Méd. trop., 31, 403.

Reinhold, J. G. (1953) Standard Methods of Clinical Chemistry, Vol. 1, p. 88, edited by Reiner, M. Academic Press, New York. Steward, V., and Gilman, L. D. (1950). American Chemical Society: Abstracts of Papers presented at 117 th meeting (Division of Biological Chemistry), p. 15C. 1955. Washington.

- Rawnesley, H. M., and Yonan V. L. (1955). Proc. of the 3rd International Congress of Biochemistry. Brussels.

Seth, D., and Dutta, B. N. (1955). Bull. Calcutta Sch. trop. Med., 3, 155 .

Stanier, M. W. (1953). Nature (Lond.), 171, 880.

and Thompson, M. D. (1954). Arch. Dis. Childh., 29, 110. 